\section{The teaching of the association between physical inactivity and non- communicable diseases in physical education classes}

\section{Ensino da associação entre inatividade física e doencas e agravios não-transmissíveis nas aulas de Educação Física}

Julia Pereira Terra

Lúcio Kerber Canabarro ${ }^{1}$

Marilda Borges Neutzling ${ }^{3}$

Nicole Gomes Gonzales $s^{1,2}$

Airton José Rombaldi ${ }^{1,2}$

\begin{abstract}
The study was conducted with physical education teachers from elementary and high schools in the urban area of Pelotas, southern Brazil, and identified the prevalence of those who taught the association of physical inactivity (PI) with non-communicable diseases (NCDs) during their classes. In addition, the moment when the content was discussed in the class and the length of time used for that purpose were investigated. We used a standardized questionnaire containing questions about the relationship between PI and NCDs, as well as information on demographic and socioeconomic aspects, career time, weekly labor hours and physical activity level. Overall, 188 teachers answered the census. Despite the high percentage of teachers who reported teaching at least one association between PI and NCDs (82.8\%), obesity being the disease most frequently mentioned $(84.7 \%)$, only $17.3 \%$ taught the association with cancer, $33 \%$ with osteoporosis and $11 \%$ of the teachers reported teaching the associations with all NCDs. As for obesity, the youngest age group (19-30 years) was the one that taught this association least frequently $(\mathrm{p}<0.001)$, with a reduction as their workload increased $(\mathrm{p}<0.03)$. A similar trend was observed regarding teaching the associations in the main part of the class $(p<0.02)$ and the time devoted to teaching them in the main part of the class $(p<0.006)$. Despite the high proportion of teachers who approached the associations between PI and NCDs during physical education classes, only the most disseminated associations by the media were taught by most teachers and by teachers with lower workloads. Health-related training activities should be offered to teachers, so that classes can include other contents beyond sports.
\end{abstract}

\section{KEYWORDS}

Teachers; Physical Activity; Chronic Disease; Health.

\section{RESUMO}

O estudo identificou a prevalência, entre os docentes de Educação Física do ensino básico da zona urbana de Pelotas/RS, aqueles que relacionavam a inatividade física (IF) com doenças e agravos não transmissíveis (DANTs) durante as aulas; além disto, foi verificado o momento da aula utilizado e o tempo destinado ao conteúdo. Utilizou-se um questionário padronizado contendo questões sobre a relação entre IF e DANTs, informações sobre aspectos demográficos, socioeconômicos, tempo de carreira, horas de trabalho semanais e nível de atividade física. Responderam ao censo 188 docentes. Apesar do elevado percentual de professores que relataram ensinar pelo menos uma associação entre IF e DANTs (82,8\%), sendo a obesidade $(84,7 \%)$ a doença mais relacionada, somente $17,3 \%$ ensinavam a relação com câncer, $33 \%$ abordavam a associação com osteoporose e $11 \%$ dos docentes relataram ensinar as associações com todas as DANTs. Em relação a obesidade, a faixa etária mais jovem (19-30 anos) era a que menos ensina sobre a associação $(p<0,001)$ e houve tendência de reduzir o ensino desta associação à medida que aumentava a carga borária do docente $(p<0,03)$. Tendência similar ocorreu com o ensino das associações na parte principal da aula $(p<0,02)$ e com o tempo destinado ao ensino na parte principal $(p<0,006)$. Concluiu-se que apenas as associações mais difundidas na mídia foram ensinadas pela maioria dos docentes e por docentes com menor carga horária. Ações de capacitação devem ser oferecidas aos professores para questões relacionadas à saúde, de modo que as aulas possam ser ministradas para além do esporte.

PALAVRAS-CHAVE

Docentes; Atividade física; Doença crônica; Saúde.
Rev Bras Ativ Fís Saúde p. 193-202 DO

http://dx.doi.org/10.12820/rbafs.v.20n2p193

1 Escola Superior de Educação Física Universidade Federal de Pelotas, RS, Brasil

2 Programa de Pós-graduação em Educação Física - Universidade Federal de Pelotas, RS, Brasil

3 Departamento de Medicina Social, Faculdade de Medicina - Universidade Federal do Rio Grande do Sul. Porto Alegre, RS, Brasil 


\section{INTRODUCTION}

According to the World Health Organization (WHO), in recent decades, non-communicable diseases (NCDs) started to rank first among the causes of death in Brazil. They passed the mortality rates by infectious and parasitic diseases of the $1980 \mathrm{~s}^{1}$ and, in 2007 , approximately $72 \%$ of the deaths in the country were attributed to $\mathrm{NCDs}^{2,3}$. According to the WHO, the social and economic transformations that occurred in Brazil during the $20^{\text {th }}$ century have brought important changes in the profile of occurrence of the diseases that affect our population.

This transition of the epidemiological scenario has affected the public health area in Brazil and the development of strategies to control the NCDs has become a priority for the Healthcare System. The epidemiological surveillance of the NCDs and its risk factors is extremely important for the implementation of public policies targeted at the prevention and control of these diseases and at the general promotion of health ${ }^{2}$.

The NCDs encompass cardiovascular problems, diabetes, obesity, cancer and respiratory diseases. They predominate in developed and developing countries and the main cause factors are stress, smoking, excessive alcohol consumption, inadequate nutrition and physical inactivity ${ }^{4}$. Thus, the current evidence clearly emphasize the association between physical inactivity and NCDs, as it is one of the main causes of the occurrence of such diseases ${ }^{5-8}$.

One of the factors that contributes to improve the population's quality of life is the enhancement of their capacity to understand phenomena related to their health. Thus, providing knowledge about a certain health outcome can be useful to help avoiding the emergence of a disease, and it may influence prevention or the search for treatment. Places of population's use, like schools, mass media and healthcare services, are potential disseminators of this information, even though the form of influencing the general population can be distinct ${ }^{1,9}$. In this context, the school is a suitable space to the development of health promotion actions, and the discipline of Physical Education $(\mathrm{PE})$ is adequate to the teaching of knowledge that will have repercussions on the youths' future, through the adoption of an active lifestyle ${ }^{5}$.

According to the (PCNs - National Curriculum Guidelines) ${ }^{6}$, the contents of the $\mathrm{PE}$ discipline are organized in three blocks, which must be developed throughout elementary and high school education: 1) sports, games, fights and gymnastics; 2) rhythmic and expressive activities; and 3) knowledge about the body. The three blocks have many contents in common that are linked among them, but each has its own specificity. The block "Knowledge about the body" has contents that are included in the others, but they can also be approached and dealt with separately. The other two have their own specific characteristics, but they are also related to each other. Within their specificity, they must approach the transversal themes, which are themes considered urgent to the country as a whole, such as the environment, ethics, health, sexual orientation, among others ${ }^{6}$.

Studies related to this theme are scarce and there is a demand to supply the area, focusing on the investigation of the relations between physical activity and health, as they are factors that, at school, are adequate to disseminate health promotion. Thus, the present study aims to identify the prevalence of 
PE teachers from elementary and high schools in the urban zone of the city of Pelotas, southern Brazil, who associated, in their classes, physical inactivity to NCDs (osteoporosis, cancer, hypertension, circulatory diseases and obesity), as well as the part of the class and the length of time they allocated to this content. Furthermore, it aims to locate factors associated with the teaching of the relationship between PI and NCDs.

\section{METHODS}

A cross-sectional census study was carried out aiming to interview all the Physical Education teachers of the 126 schools of the urban zone of Pelotas, southern Brazil, in 2009.

We requested of the Municipal Education Department, responsible for the public municipal schools, and of the $5^{\text {th }}$ Regional Coordination of Education, in charge of state-run and private schools, authorization to conduct the research in the teaching institutions. We asked for a list of all the schools existing in the urban zone of the municipality, and this document guided data collection.

The instrument used in this study was a standardized questionnaire developed by the researchers. It contained demographic and socioeconomic variables, and also variables related to career time (categorized as 0-5 years/6-15 years/16-25 years/ $\geq 26$ years), weekly labor hours (categorized as up to 20 hours/21-40 hours/ $\geq 41$ hours), and physical activity level, measured through the IPAQ (International Physical Activity Questionnaire) - long version ${ }^{10}$, so that other pieces of information related to the subjects' physical activity level were used in other studies ${ }^{11}$. In addition, the following variables were collected: socioeconomic level (determined according to the classification of - ABEP (Brazilian Association of Research Companies) ${ }^{12}$; body mass index (BMI - calculated from the values of self-referred weight and height, and categorized as eutrophic and overweight/obesity); sex (categorized as male/ female); age (collected in full years and transformed into four categories - 1930 years/31-40 years/41-50 years/ $\geq 51$ years); smoking (smoker, ex-smoker, never smoked); and self-rated health (excellent, very good and regular/poor).

The outcome of the present study was the knowledge about the relationship between PI and NCDs. It was collected through the question "In relation to knowledge about the relationship between PI and health, have you ever approached any of the following diseases (osteoporosis, cancer, hypertension, circulatory diseases and obesity) and their relationship to physical inactivity with your students?", and was categorized as yes/no. The subjects who answered "yes" were asked about the length of time they allocated to deal with this content in the classes (answers categorized as $<30$ minutes/ $\geq 30$ minutes) and at which moment of the class such approach took place (answers categorized as main part/other moments).

The questionnaires were self-administered. Overall, 98.9\% were answered at school and, in some cases, the collection was performed at another workplace (health clubs) or at the professional's home. All the teachers who were teaching classes in the period of data collection were considered part of the sample. Institutionalized teachers (prison, clinical and/or psychiatric hospital) and teachers who were on leave were excluded from the study. Information 
on the number of Physical Education teachers who worked in the school was provided by the headmaster or pedagogical coordinator. In case of doubt, the school records were consulted.

Refusals were considered when the teachers expressed the desire of not participating in the study twice, with a minimum interval of one week. The data collection period occurred from June to December 2009.

We had the support of nine students from the nutrition and physical education undergraduate programs of (interviewers), to make the contact with the teachers. The scholars underwent a 12-hour training. These research assistants helped the subjects to understand the questionnaire and solved doubts while they were answering it. Ten percent of the research subjects were drawn for quality control, which was performed through contacts via telephone with the teachers and through visits to the schools. In the re-interviews, 15 pre-selected questions were administered in order to verify the consistency of the answers. In case of inconsistency, the interviews were re-conducted.

Data were entered twice in the software Epi-Info 6.0 and, after the automatic check of amplitude and consistency, they were transferred to the statistical package Stata 12.0. Both a univariate analysis (with description of the variables, presented through mean and standard deviation for continuous variables and percentage for categorical variables) and a bivariate analysis (through Pearson's chi-square test and chi-squared test for linear trend) were used. Statistical significance was set at 0.05 .

All the participants signed a consent document. The study was approved by the Ethics Committee of of, under the protocol number 032/2009.

\section{RESULTS}

The total number of Physical Education teachers in 2009 working in the public and private schools of the urban zone of the city of Pelotas, southern Brazil, was 212. Of these, 188 answered the questionnaire, representing a response rate of $88.7 \%$.

Table 1 presents the characterization of the sample. The majority of the individuals were of the female sex $(61.7 \%)$, aged between 31 and 50 years (70.3\%), belonged to the socioeconomic level B $(68.6 \%)$, never smoked $(78.5 \%)$, self-rated their health as very good (77.0\%), their career time was less than 25 years $(67.2 \%)$, their BMI was eutrophic $(60.9 \%)$, worked between 21 and 40 hours per week (51.4\%), and explained at least one association between PI and NCDs (82.8\%).

Despite the high proportion of teachers who reported teaching at least one association between PI and NCDs, when the teaching of the association with each NCD was verified, the prevalences were diverse. Thus, only $17.3 \%$ taught the relationship between PI and cancer, $33 \%$ approached the association between PI and osteoporosis, $62.7 \%$ reported they associated PI and circulatory diseases, $66.0 \%$ included in their content the association between PI and hypertension and $84.9 \%$ approached the association between PI and obesity. In addition, only $11 \%$ of the teachers reported teaching that PI represents a risk to develop all the NCDs considered in this study.

The analysis showed statistical significance in the teaching of the relationship between some NCDs and PI. There was an association for the teaching 
TABLE 1 - Description of the Physical Education teachers from the schools of Pelotas, southern Brazil, according to sociodemographic, behavioral, nutritional, health and labor variables ( $n=188$ ).

\begin{tabular}{|c|c|c|}
\hline \multirow[t]{2}{*}{ Variables } & \multicolumn{2}{|c|}{ Total } \\
\hline & N & $\%$ \\
\hline \multicolumn{3}{|l|}{ Sex $(n=188)$} \\
\hline Male & 72 & 38.3 \\
\hline Female & 116 & 61.7 \\
\hline \multicolumn{3}{|c|}{ Age (years) (n=188) } \\
\hline $19-30$ years & 33 & 17.5 \\
\hline $31-40$ years & 58 & 30.9 \\
\hline $41-50$ years & 74 & 39.4 \\
\hline$>50$ years & 23 & 12.2 \\
\hline \multicolumn{3}{|c|}{ Socioeconomic level ( $n=188$ ) } \\
\hline A (highest) & 59 & 31.4 \\
\hline B & 129 & 68.6 \\
\hline \multicolumn{3}{|c|}{ Career time (years) $(n=188)$} \\
\hline $0-5$ years & 47 & 25.0 \\
\hline $6-15$ years & 69 & 36.7 \\
\hline $16-25$ years & 48 & 25.5 \\
\hline$>25$ years & 24 & 12.8 \\
\hline \multicolumn{3}{|c|}{ Weekly labor hours ( $n=173$ ) } \\
\hline Up to 20 hours & 42 & 24.3 \\
\hline 21-40 hours & 89 & 51.4 \\
\hline$>40$ hours & 42 & 24.3 \\
\hline \multicolumn{3}{|l|}{ Smoking $(n=186)$} \\
\hline Smoker & 16 & 8.6 \\
\hline Ex-smoker & 24 & 12.9 \\
\hline Never smoked & 146 & 78.5 \\
\hline \multicolumn{3}{|c|}{ Self-rated health $(n=187)$} \\
\hline Excellent & 35 & 18.7 \\
\hline Very good & 144 & 77.0 \\
\hline Regular/poor & 8 & 4.3 \\
\hline \multicolumn{3}{|c|}{ Body mass index $\left(\mathrm{kg} / \mathrm{m}^{2}\right)(\mathrm{n}=184)$} \\
\hline Eutrophic & 112 & 60.9 \\
\hline Overweight & 72 & 39.1 \\
\hline \multicolumn{3}{|c|}{ Teacher explains the association PI and NCDs ( $n=186$ ) } \\
\hline Yes & 154 & 82.8 \\
\hline No & 32 & 17.2 \\
\hline
\end{tabular}

$\mathrm{PI}=$ Physical Inactivity; NCDs=Non-communicable diseases

of the relationship between PI and hypertension and between PI and cancer ( $\mathrm{p}=0.01$ and $\mathrm{p}=0.03$, respectively) according to the BMI of the interviewed teachers (Table 2): more teachers that are overweight taught the associations compared to their eutrophic colleagues. Table 3 presents the association for the teaching of the relationship between IP and obesity according to the variables age and weekly labor hours. It is possible to verify that the youngest age group was the one that taught the association between IP and obesity least frequently $(\mathrm{p}<0.001)$; furthermore, there was a trend to reduce this teaching 
TABLE 2 - Association of teaching the relationship between physical inactivity and hypertension/cancer according to the body mass index of the Physical Education teachers of the city of Pelotas, Southern Brazil.

\begin{tabular}{|c|c|c|c|c|c|c|c|c|c|c|}
\hline \multirow{4}{*}{ Variables } & \multirow{2}{*}{\multicolumn{4}{|c|}{$\begin{array}{c}\text { Teaches the relationship between } \\
\text { Hypertension and PI }\end{array}$}} & \multicolumn{6}{|c|}{$\begin{array}{l}\text { Teaches the relationship between } \\
\text { Cancer and PI }\end{array}$} \\
\hline & & & & & \multirow{3}{*}{$\mathrm{p}$-value } & & & & & \multirow{2}{*}{$\mathrm{p}$-value } \\
\hline & \multicolumn{2}{|c|}{ Yes } & \multicolumn{2}{|c|}{ No } & & & & & & \\
\hline & $\mathrm{N}$ & $\%$ & $N$ & $\%$ & & $\mathrm{~N}$ & $\%$ & $N$ & $\%$ & \\
\hline BMI $\left(\mathrm{kg} / \mathrm{m}^{2}\right)$ & & & & & $0.01^{a}$ & & & & & $0.03^{a}$ \\
\hline Eutrophic & 65 & 59.1 & 45 & 40.9 & & 14 & 12.7 & 96 & 87.3 & \\
\hline Overweight & 55 & 77.5 & 16 & 22.5 & & 18 & 25.4 & 53 & 74.6 & \\
\hline
\end{tabular}

$\mathrm{PI}=$ Physical Inactivity; BMI = body mass index; a Pearson's chi-square test

TABLE 3 - Association of teaching the relationship between obesity and physical inactivity according to the age and weekly labor hours of the Physical Education teachers of the city of Pelotas, southern Brazil, 2009.

\begin{tabular}{|c|c|c|c|c|c|}
\hline \multirow{3}{*}{ Variables } & \multicolumn{4}{|c|}{ Teaches the Relationship between Obesity and PI } & \multirow[t]{3}{*}{$\mathrm{p}$-value } \\
\hline & \multicolumn{2}{|c|}{ Yes } & \multicolumn{2}{|c|}{ No } & \\
\hline & $\mathrm{N}$ & $\%$ & $\mathrm{~N}$ & $\%$ & \\
\hline Age & & & & & $0.001^{a}$ \\
\hline $19-30$ years & 21 & 65.6 & 11 & 34.4 & \\
\hline $31-40$ years & 53 & 93.0 & 4 & 7.0 & \\
\hline $41-50$ years & 66 & 90.4 & 7 & 9.6 & \\
\hline$>50$ years & 17 & 73.9 & 6 & 26.1 & \\
\hline Weekly labor hours & & & & & $0.03^{b}$ \\
\hline Up to 20 hours & 31 & 75.6 & 10 & 24.4 & \\
\hline $21-40$ hours & 74 & 84.1 & 14 & 15.9 & \\
\hline$>40$ hours & 39 & 92.9 & 3 & 7.2 & \\
\hline
\end{tabular}

a Pearson's chi-square test; $\mathrm{b}$ Chi-squared test for linear trend; $\mathrm{PI}=$ physical inactivity

as the number of labor hours increased $(\mathrm{p}<0.03)$.

As for the length of time allocated to the teaching and the part of the class in which they approached the matter PI and NCDs, we found an association with the variable weekly labor hours (Table 4). There was a trend of reducing the utilization of the main part of the class to teach as the number of labor hours increased $(\mathrm{p}<0.02)$. Concerning the time allocated by the teachers to teach the association between PI and NCDs, it was observed that there was a trend of reducing the time as the number of labor hours increased $(\mathrm{p}<0.006)$.

Moreover, almost half of the teachers ( $45 \%$ ) reported using the main part of the class to explain the content discussed here; however, the time allocated to approach the relationship between PI and NCDs was short: one third of the interviewees (35\%) used 5 to 10 minutes to discuss it.

Figure 1 presents the proportion of Physical Education teachers in the city of Pelotas who taught one or more relationships between PI and NCDs, according to sex. There was no significant association, but it is important to notice that, except in the teaching of the association between PI and five diseases, the women presented higher prevalences of teaching the diseases. 
TABLE 4 - Association of weekly labor hours according to the part of the class and the length of time allocated to the teaching of the relationship between physical inactivity and non-communicable diseases by the Physical Education teachers of the city of Pelotas, southern Brazil, 2009.

\begin{tabular}{|c|c|c|c|c|c|c|c|c|c|c|}
\hline \multirow{3}{*}{ Variables } & \multicolumn{4}{|c|}{$\begin{array}{l}\text { Part of the class in which teaches the } \\
\text { association between PI and NCDs }\end{array}$} & \multirow[t]{3}{*}{$p$-value } & \multicolumn{4}{|c|}{$\begin{array}{l}\text { Length of time allocated to the teaching of } \\
\text { the association between } \mathrm{PI} \text { and } \mathrm{NCDs}\end{array}$} & \multirow[t]{3}{*}{$p$-value } \\
\hline & \multicolumn{2}{|c|}{ Main Part } & \multicolumn{2}{|c|}{ Other Moments } & & \multicolumn{2}{|c|}{$<30 \mathrm{~min}$} & \multicolumn{2}{|c|}{$\geqslant 30 \mathrm{~min}$} & \\
\hline & $\mathrm{N}$ & $\%$ & $\mathrm{~N}$ & $\%$ & & $\mathrm{~N}$ & $\%$ & $\mathrm{~N}$ & $\%$ & \\
\hline Weekly labor hours & & & & & $0.02^{\mathrm{a}}$ & & & & & $0.006^{a}$ \\
\hline Up to 20 hours & 20 & 66.7 & 10 & 33.3 & & 14 & 45.2 & 17 & 54.8 & \\
\hline $21-40$ hours & 27 & 42.2 & 37 & 57.8 & & 43 & 68.3 & 20 & 31.7 & \\
\hline$>40$ hours & 13 & 36.1 & 23 & 63.9 & & 28 & 77.8 & 8 & 22.2 & \\
\hline
\end{tabular}

a Chi-squared test for linear trend; PI = physical inactivity; NCDs = Non-communicable diseases

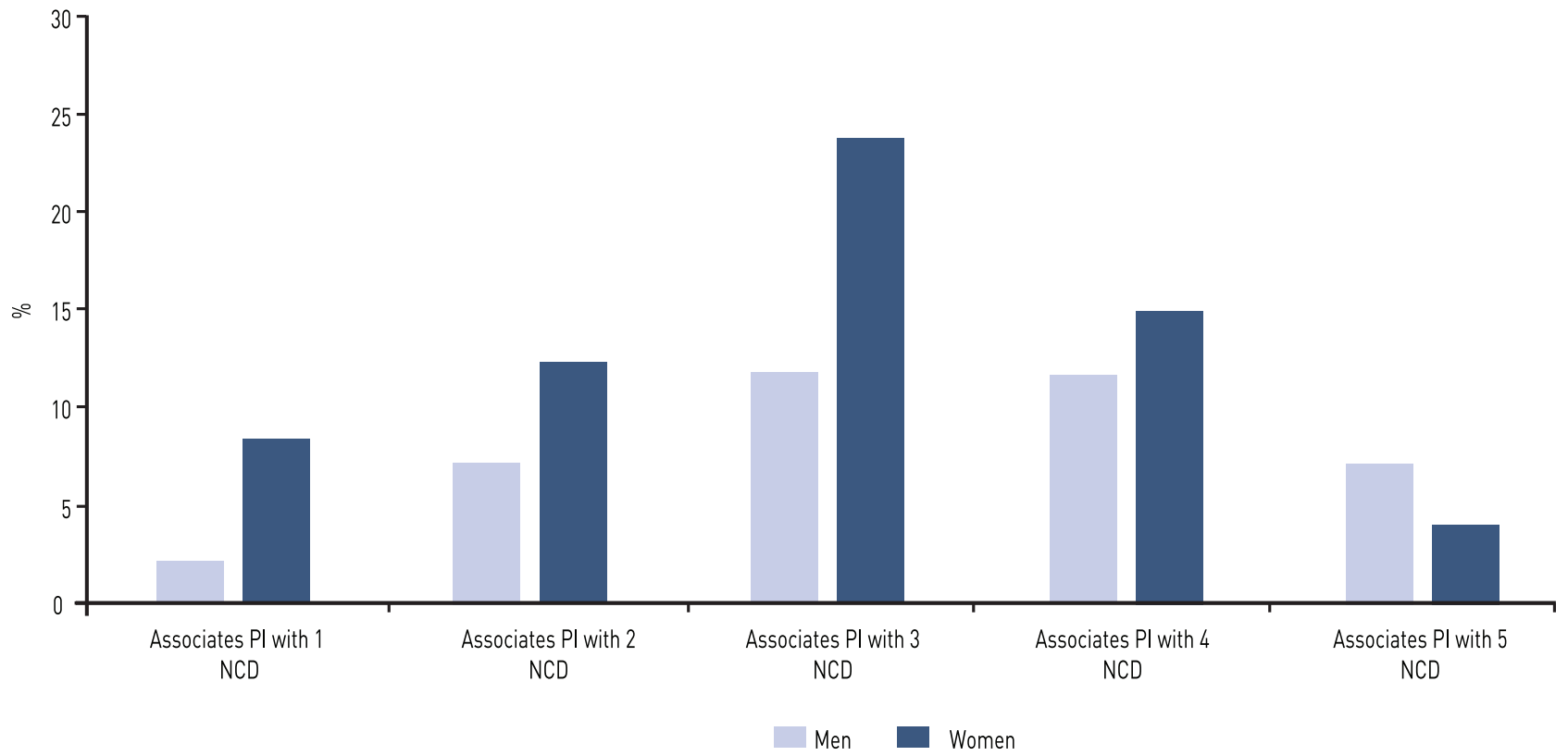

FIGURE 1 - Proportion of Physical Education teachers of the city of Pelotas, southern Brazil who taught one or more relationships between physical inactivity (PI) and non-communicable diseases (NCDs) according to sex. 2009. (teaching of the association of PI with one NCD - $p=$ 0.02 ; teaching of the association of PI with two NCDs $-p=0,001$; teaching of the association of PI with three NCDs - $p=0.3$; teaching of the association of PI with four NCDs - $p=0.8$; teaching of the association of PI with five NCDs $-p=0.2$ ).

\section{DISCUSSION}

This study found a high percentage of teachers who reported that they teach the association between physical inactivity and NCDs (82.8\%). The most associated diseases were the ones that are more frequently disseminated by the media (hypertension $-66.0 \%$, circulatory diseases $-62.7 \%$ and obesity $-84.7 \%)^{1,13}$. The other diseases had a low prevalence of teaching, which shows the possibility that the teachers use more frequently the means of communication to keep themselves up-to-date, to the detriment of conferences and scientific journals in the area. It is important to highlight that Brazil has biannual edition of a scientific congress and a scientific journal specific to the 
area of physical activity and health (Brazilian Congress of Physical Activity and Health ${ }^{14}$ and Brazilian Journal of Physical Activity and Health ${ }^{15}$ ), as well as other events and journals that deal with the matter ${ }^{16}$.

A positive aspect of the study was its census nature and the fact that it had a low rate of losses and refusals (11.3\%). On the other hand, the small number of studies carried out with physical education teachers and the lack of studies approaching the teaching of the association between PI and NCDs among a population of teachers hindered the comparison of the findings of the present study.

Regarding the association between teaching the relationship of obesity to PI according to age and weekly labor hours, the younger teachers were the ones who taught this relation least frequently. This was possibly caused by the fact that youths have a lower perception of risk factors and their impact on diseases, and give less importance to them. Studies on AIDS and sedentarism have found similar associations ${ }^{17,18}$. On the other hand, it was observed that middle-aged teachers $(31-50$ years) were the ones that most drew this relationship $(\mathrm{p}<0.001)$. We have not found studies that reported specifically this result with teachers. Thus, it is possible that the result occurred because it is in this age group that chronic diseases like hypertension start to emerge ${ }^{19,20}$, which led the teachers who belong to this age group to approach the association more emphatically.

As for the associations of weekly labor hours with the moment in which the contents were approached during the class and with the length of time allocated to the discussion of this content, the teachers with the lowest workload per week were the ones who most used the main part of the class to relate PI and NCDs $(\mathrm{p}<0.02)$ and who used more time of this part of the class to teach the content $(\mathrm{p}<0.006)$. We have not found other studies with physical education teachers to compare the present findings. However, as far as teachers are concerned, these results are not uncommon, as the highest their workload (either teaching classes or developing administrative activities), the lowest the time destined to plan classes and attend recycling courses ${ }^{21-24}$. On the other hand, a recent study ${ }^{25}$ that contextualized the Physical Education classes and contents that are developed in elementary and high school education in the city of Pelotas corroborates the results of the present study. It reported that only $16.6 \%$ of the theoretical contents focused on the benefits of physical activity for health. In the present study, less than $1 / 4$ of the teachers had a workload of 20 hours per week, which allowed them to plan activities that provided knowledge about the association between PI and NCDs.

The results indicated that the teachers whose BMI was in the overweight category were the ones who most related PI to the NCDs hypertension and cancer in their classes. We have not found studies that presented results with teachers for comparison. On the other hand, unlike the findings of this research, a study conducted with health professionals ${ }^{26}$ has shown that overweight individuals may be more careless about their health and may not emphasize the risks of overweight to their students, a fact that is quite disturbing, as there is no doubt about the association between overweight/obesity and hypertension ${ }^{27}$.

Overweight individuals were the ones who most reported teaching the association between PI and cancer. Taking into consideration that the relations between cancer and body weight occur in a few types of cancer (such as breast, prostate, colon and rectal cancer ${ }^{28}$ ), it is surprising that the teachers empha- 
sized this relation (overweight and cancer). This association is not disseminated in an explicit way to the population. The media usually emphasizes the relation between body weight and hypertension ${ }^{29}$.

In view of the results of the present study, it is possible to conclude that, despite the high proportion of teachers who reported teaching the association between PI and NCDs during the Physical Education classes, only the associations that are disseminated by the media were taught by the majority of the teachers. Furthermore, this content was taught during the least important parts of the class.

The results are worrisome, as the physical education teachers, as a health professionals, have a huge potential to provide students with knowledge about the harms of PI. Therefore, health-related training activities should be offered to teachers, so that the classes can include other contents beyond sports.

\section{REFERENCES}

1. World Health Organization. World health statistics 2012. Geneva: WHO, 2012.

2. Brasil. Ministério da Saúde. Secretaria-Executiva. Secretaria de Vigilância em Saúde. Glossário temático: promoção da saúde / Ministério da Saúde. Secretaria-Executiva. Secretaria de Vigilância em Saúde. Brasília/DF: Editora MS; 2012.

3. Silva-Junior JB. As doenças transmissíveis no Brasil: tendências e novos desafios para o Sistema Único de Saúde. Ministério da Saúde. Secretaria de Vigilância em Saúde. Departamento de Análise de Situação de Saúde. Brasília: Ministério da Saúde, 2009.

4. Sociedade Brasileira de Cardiologia, Sociedade Brasileira de Hipertensão, Sociedade Brasileira de Nefrologia. V Diretrizes Brasileiras de Hipertensão Arterial.Arq Bras Cardiol. 2010; 1(supl 1):1-51.

5. Pate RR, Davis MG, Robinson TN, Stone EJ, Mckenzie TL, Young JC. Promoting physical activity in children and youth : a leadership role for schools: a scientific statement from the American Heart Association Council on Nutrition, Physical Activity, and Metabolism (Physical Activity Committee) in collaboration with the Councils on Cardiovascular Disease in the young and Cardiovascular Nursing. Circulation. 2006; 114(11):1214-24.

6. Brasil. Secretaria de Educação Fundamental. Parâmetros Curriculares Nacionais : Educação Física /Secretaria de Educação Fundamental. Brasília: MEC/SEF, 1998. 114 p.

7. Blair SN. Physical inactivity: the biggest public health problem of the 21 st century. $\mathrm{Br}$ J Sports Med. 2009;43(1):1-2.

8. Trost SG, Blair SN, Khan Km. Physical inactivity remains the greatest public health problem of the 21st century: evidence, improved methods and solutions using the ' 7 investments that work' as a framework. Br J Sports Med. 2014; 48(3):169-70.

9. Vuori I, Paronen O, Oja P. How to develop local physical activity promotion programmes with national support: the Finnish experience. Patient Educ Couns. 1998; 33(Suppl 1):S111-9.

10. Craig CL, Marshall AL, Sjöström M, Bauman AE, Booth ML, Ainsworth BE, et al. International physical activity questionnaire: 12 -country reliability and validity. Med Sci Sports Exer. 2003; 35(8):1381-95.

11. Canabarro LK, Neutzling MB, Rombaldi AJ. Nível de atividade física no lazer dos professores de educação física do ensino básico. Rev Bras Ativ Saúde. 2011; 16(1):11-7.

12. Associação Brasileira de Empresas de Pesquisa. Critério de classificação econômica do Brasil - 2009. São Paulo: ABEP, 2009.

13. Borges TT, Rombaldi AJ, Knuth AG, Hallal PC. Conhecimento sobre fatores de risco para doenças crônicas: estudo de base populacional. Cad Saude Publica. 2009; 25(7):1511-20.

14. IX Congresso Brasileiro de Atividade Física e Saúde. Anais do Congresso Brasileiro de Atividade Física e Saúde. Sociedade Brasileira de Atividade Física e Saúde, 2013: Curitiba - PR. p. 304. 
15. Barros MVG, Rombaldi AJ, Borges TT, Florindo AA. Revista Brasileira de Atividade Física \& Saúde: experiências e processos editoriais. Rev Bras Ciênc Esporte. 2014; 36(4):746-51.

16. Kienteka M, Stocchero CMA, Fueyo JL, Andrade RLM, Peixoto MB. Atividade física e saúde: produção científica em periódicos da Educação Física no Brasil. Rev Bras Ativ Fis e Saúde. 2014; 19(4):410-12.

17. Benincasa M, Rezende MM, Coniaric J. Sexo desprotegido e adolescência: fatores de risco e de proteção. Psicol Teor Prat (Impr) 2008; 10(2):121-34.

18. Araujo DSMS, Araujo CGS. Aptidão física, saúde e qualidade de vida relacionada à saúde em adultos. Rev Bras Med Esporte. 2000; 6(5):194-203.

19. Sociedade Brasileira de Cardiologia / Sociedade Brasileira de Hipertensão / Sociedade Brasileira de Nefrologia. VI Diretrizes Brasileiras de Hipertensão. Arq Bras Cardiol. 2010; 95(Suppl 1):1-51.

20. Gordilho A, Sérgio J, Silvestre J, Ramos LR, Freire MPA, Espindola N, et al. Desafios a serem enfrentados no terceiro milênio pelo setor saúde na atenção ao idoso. Rio de Janeiro: UnATI/UERJ, 2000. 92p.

21. Sousa AA, Sousa TP, Queiroz MP, Silva ESL. Evasão escolar no ensino médio: velhos ou novos dilemas? Vértices. 2011; 13(1):25-37.

22. Rodrigues LFR. Representações sociais de professores sobre o projeto "Prevenção Também se Ensina": uma abordagem psicossocial [dissertação de mestrado]. Ribeirão Preto: Centro Universitário Moura Lacerda; 2008.

23. Garcia MMA, Anadon SB. Reforma educacional, intensificação e autointensificação do trabalho docente. Educ Soc. 2009; 30(106):63-85.

24. Instituto Paulo Montenegro. Ser professor: uma pesquisa sobre o que pensa o docente das principais capitais brasileiras. Estudos \& Pesquisas Educacionais (Fundação Victor Civita - São Paulo): 2010;(1):17-61.

25. Fortes MO, Azevedo MR, Kremer MM, Hallal CP. A educação física escolar na cidade de Pelotas-RS: contexto das aulas e conteúdos. Rev Educ Fis/UEM. 2012; 23(1):69-78.

26. Teixeira FV, Pais-Ribeiro JL, Maia ARPC. Crenças e práticas dos profissionais de saúde face à obesidade: uma revisão sistemática. Rev Assoc Med Bras. 2012; 58(2):254-62 .

27. Carneiro G, Faria AN, Ribeiro Filho FF, Guimarães A, Lerário D, Ferreira SRG, et al. Influência da distribuição da gordura corporal sobre a prevalência de hipertensão arterial e outros fatores de risco cardiovascular em indivíduos obesos. Rev Assoc Med Bras. 2003; 49(3):306-11.

28. Guerra MR, Moura Gallo CV, Mendonça GAS. Risco de câncer no Brasil: tendências e estudos epidemiológicos mais recentes. Rev Bras Cancerol. 2005; 51(3):227-34.

29. Silva JP, Bousfield ABS, Cardoso LH. A hipertensão arterial na mídia impressa: análise da revista Veja. Psicol Saber Soc 2013; 2(2):191-203.

CORRESPONDING AUTHOR

NICOLE GOMES GONZALES

Rua Doutor Benjamin Gastal, 57 - Bairro 